\title{
Morphology, palynology, and stipe anatomy of four common ferns from Pekanbaru, Riau Province, Indonesia
}

\author{
NERY SOFIYANTI, DYAH IRIANI, FITMAWATI, AFNI ATIKA MARPAUNG \\ Department of Biology, Faculty of Mathematics and Natural Sciences, Universitas Riau. Jl. H.R. Soebrantas Km 12.5, Kampus Binawidya, Pekanbaru \\ 28293, Riau, Indonesia. Tel./fax.+62-761-63273, `email: nery.sofiyanti@lecturer.unri.ac.id, nery_yusuf@yahoo.com
}

Manuscript received: 28 September 2017. Revision accepted: 30 December 2018.

\begin{abstract}
Sofiyanti N, Iriani D, Fitmawati, Marpaung AA. 2019. Morphology, palynology, and stipe anatomy of four common ferns from Pekanbaru, Riau Province, Indonesia. Biodiversitas 20: 327-336. The fern explorations had been conducted in Pekanbaru, Riau Province from 2013 to 2017. The objectives of this study were to characterize the morphological characters, to examine the spore features and stipe anatomy characters of four common ferns from Pekanbaru. The specimens were collected from the fields using the exploration method from 21 study sites from 10 sub-districts. The spores were then observed using a digital microscope. A total of four fern species were known as the most common fern species in this region, i.e., Dicranopteris linearis, Stenochlaena palustris, Nephrolepis biserrata, and Davalia denticulata. This study examined the morphology, palynology and stipe anatomy of these four common ferns from Pekanbaru, Riau. The anatomical preparation was conducted using paraffin method while spore preparation using acetolysis method. We found dimorphic ferns (Stenochlaena palustris and Davallia denticulata) and monomorphic ferns (Dicranopteris linearis and Nephrolepis biserrata). The vascular bundle of stipes of four species examined is similar, i.e., amphicribral concentric, however, the vascular bundles within the species varies in size. We also observed similar type of stele, atactostele, among the species. The spore features found in this study were monolete and trilete with prolate and subprolate shape. The result of this study supports the anatomical data of the examined species.
\end{abstract}

Keywords: Dimorphic, monolete, monomorphic, trilete

\section{INTRODUCTION}

Fern is a lower plant group that characterized by being vascular and having spore. The presence of vascular bundle distinguishes this group from mosses. Most of the fern species have crozier, a juvenile with fiddlehead. This structure forms a coiled young frond. However, fern members from this following genera: Equisetum (Guillon 2004), Psilotum (Vahdati et al. 2014), Salvinia, and Marsilia are lack of this structure (Nagalingum et al. 2006). The members of the fern group are cosmopolitan species, that widely distributed in the world, especially in tropical regions. This plant group consists of up to 12.000 species (Aldasoro et al. 2004).

The exploration of fern from Riau Province have been conducted from 2010 to present (Sofiyanti 2013; Wulandari et al. 2016; Sofiyanti et al. 2015a; Yusna et al. 2016) and identified a total of 112 fern species. Some fern species have high abundances and very common in this province, including in the capital city, Pekanbaru. In spite of the development of this city reduce the habitat of this ferns, however, there are many locations remain for fern habitat. The epiphytic ferns can be found on the ornamental roadside trees, abandoned broken fence or wall, or on crop trees such as Nephelium lappaceum (Rambutan), Mangifera indica (Mango) and Elaeis guineensis (Oil palm) (Sofiyanti 2013; Sofiyanti et al. 2015a). While the terrestrial ferns occur on the ground of forest city, roadside, yard, garden or other open space areas. This study indicated the most common fern that much abundance in Pekanbaru, Riau Province, i.e., Dicranopteris linearis, Stenochlaena palustris, Nephrolepis bisserata and Davallis denticulata. The finding supports us to examine the detailed morphology, palynology, and stipe anatomy of these four common ferns.

Morphology is the most common evidence in plant taxonomic. Many taxonomists used this character for taxonomic works for description, identification, classification as well as in determining a new species (Huiet et al. 2015; Lindsay et al. 2008; Rojas-Alvarado 2017; Sofiyanti et al. 2015a; Sofiyanti et al. 2016). Palynology is a study on the characteristic of spore (in Cryptogamae such as mosses and fern) and pollen (Phanerogamae or Spermatophyta). Palynological data supports the taxonomic status of a species due to the constant characteristic of spore or pollen (Moran et al. 2007; Sofiyanti et al. 2017; Zenkteler 2012). While the anatomical data is also important for examining the inner structure of a taxon, including the anatomy of stipes. The objectives of this study were to characterize the morphological, to examine the spore features, and stipe anatomy characters of four common ferns from Pekanbaru. 


\section{MATERIALS AND METHODS}

\section{Samples collection}

All samples were collected from the field using the exploration method. A total of 21 study sites from 10 sub- districts were selected based on the fern occurrence (Table 1). We used direct observation to select the common and abundant ferns that found in 21 study sites. Each selected species was photographed before being prepared for herbarium.
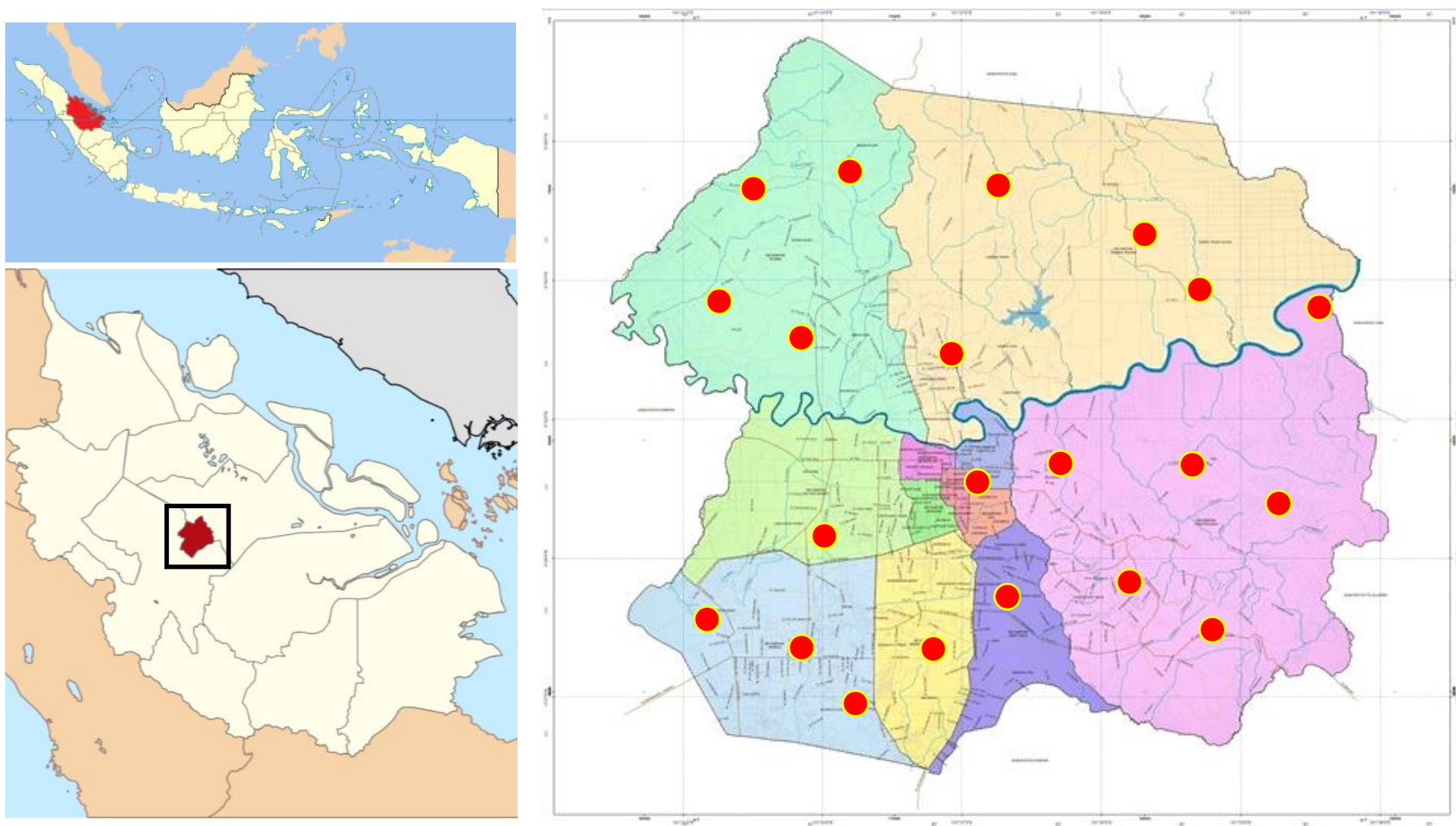

Figure 1. Map of study sites in Pekanbaru City, Riau, Indonesia

Table 1. List of study sites and examined specimens in Pekanbaru City, Riau, Indonesia

\begin{tabular}{|c|c|c|}
\hline Sub district & Study sites & Speciemen voucher \\
\hline Bukit Raya & $\begin{array}{l}\text { Tangkerang, Tangkerang Selatan, } \\
\text { Simpang Tiga }\end{array}$ & $\begin{array}{l}\text { DL1A*, DL1B Tangkerang; DL1C, Simpang Tiga; SP1A, SP1B, SP1C, NB1A, } \\
\text { NB1B, NB1C Simpang Tga; DD1A, DD1B, Simpang Tiga, DD1C Tangkerang } \\
\text { Selatan, Collector Nery } 2016\end{array}$ \\
\hline Maha Ratu & $\begin{array}{l}\text { Marpoyan Damai, Maha Ratu, } \\
\text { Sido Mulyo, Tangkerang Barat }\end{array}$ & $\begin{array}{l}\text { DL2A, DL2B, DL2C Marpoyan Damai; SP2A Marpoyan Damai; SP2B*, SP2C } \\
\text { Maha Ratu; NB2A, NB2B Marpoyan Damai, NB2C Maha Ratu; DD2A Maha } \\
\text { Ratu; DD2B, DD2C Tangkerang Barat, Collector Nery } 2016\end{array}$ \\
\hline Payung Sekaki & Tampan & $\begin{array}{l}\text { DL3A, DL3B, DL3C; SP3A, SP3B, SP3C; NB3A*, NB3B, NB3C; DD3A, } \\
\text { DD3B, DD3C Tampan, Collector Nery \& Erlina } 2016 .\end{array}$ \\
\hline Rumbai & Rumbai & $\begin{array}{l}\text { DL4A Palas; DL4B, DL4C; SP4A, SP4B, SP4C, NB4A, NB4B, NB4C; DD4A, } \\
\text { DD4BN DD4C Rumbai Collector Nery, Dyah, Afni, Machfira, Ayu } 2016\end{array}$ \\
\hline Rumbai Pesisir & Limbungan & $\begin{array}{l}\text { DL5A, DL5B, DL5C; SP5A, NB5A, NB5B, NB5C; DD5A, DD5BN DD5C } \\
\text { Limbungan Collector Nery } 2017\end{array}$ \\
\hline Sukajadi & Sukajadi, Kampung Tengah & $\begin{array}{l}\text { DL6A, NB6A Sukajadi; DD6A, DD6B Suakajadi DD6C Kampung Tengah } \\
\text { Collector Nery } 2016\end{array}$ \\
\hline Tampan & $\begin{array}{l}\text { Tampan, Delima, Sidomulyo } \\
\text { Barat }\end{array}$ & $\begin{array}{l}\text { DL7A, Tampan; SP7A, SP7B, SP7C Tampan; NB7A, NB7B, NB7C Tampan; } \\
\text { DD7A* Sidomulyo Barat Collector Nery 2016; DD7B Tampan Collector Erlina } \\
2017 \text { DD7C Delima Collector Nery } 2016\end{array}$ \\
\hline Tenayan Raya & Kulim, Tangkerang Timur & $\begin{array}{l}\text { DL8A, DL8B, SP8A, SP8B, NB8A, NB8B, NB8C; DD8A, DD8B Kulim ; } \\
\text { DD8C Tangkerang Timur, Collector Nery } 2016\end{array}$ \\
\hline Sail & Cinta Raja, Suka Maju & $\begin{array}{l}\text { DL9A Suka Maju; SP9A, NB9A, DD9A, DD9B, DL9C Cinta Raja Collector } \\
\text { Nery } 2016\end{array}$ \\
\hline Senapelan & Kampung Dalam & DL110A, SP110A, NB110A, DL110A, Kampung Dalam Collector Nery 2016 \\
\hline
\end{tabular}

Note: All of the speciemens were deposited in Herbarium Riauensis. DL $=$ Dicranopteris linearis, $\mathrm{SP}=$ Stenochlaena palustris, $\mathrm{NB}=$ Nephrolepis biserrata, DD = Davalia denticulata. $*$ Specimens used for palynological and anatomical studies 


\section{Morphological study and identification}

The detail morphological observation of generative and vegetative organs was carried out for each species identified. Identification was made mainly based on Piggiot (1998), Sofiyanti et al. (2015b) as well as based on the fern collections from Herbarium Riauensis. The accepted name and synonyms of each species were checked in http://www.theplantlist.org.

\section{Palynological study}

Spores preparation using acetolysis method based on Johansen (1940). The spore materials were fixed in Glacial Acetic Acid (GAA) for $24 \mathrm{~h}$. and were then centrifuged using hand centrifuge for $5 \mathrm{~min}$ before being put in the GAA: $\mathrm{H}_{2} \mathrm{SO}_{4}$ solution (9:1). The heating of materials for 15 min. was done using water bath, before centrifugation for 5 min. Replaced the solution with the mixture of GAA (2 $\mathrm{mL}$ ), 3 drops of $\mathrm{Na}$ Chlorate and 3 drops of $\mathrm{HCl}$, followed by 5 min. centrifugation. The washing step was conducted 3 times by replacing the solution with $\mathrm{dH}_{2} \mathrm{O}$, and the materials were then stained in the mixture of $1 \%$ safranin and glycerin. The spore morphology was observed and photographed with USB Digital Microscope (Brand HOT). The measurement of spore length was conducted based on 20 pollen grains each species. The determination of spore characteristic followed Ertdman (1957). The spore materials were also photographed using a digital microscope (Celeron).

\section{Anatomical study}

The stipes were only collected from frond bearing spore. The preparation of stipe anatomy used paraffin method following Johansen (1940). The stipe materials were fixed in Formalin-acetic acid-alcohol (FAA) for $24 \mathrm{~h}$. The materials were then removed from the FAA and placed in ethanol dehydration series ( $70 \%$ for $30 \mathrm{~min}, 80 \%$ for 30 $\min , 95 \%$ for $30 \mathrm{~min}, 100 \%$ for $30 \mathrm{~min}$ and $100 \%$ for 60 min). This dehydration was followed by dealchoholization by placing the material in this following solution, ethanol: xylol (3:1, 1:1, 1:3 for $30 \mathrm{~min}$. each), xylol for $30 \mathrm{~min}$ twice, and the mixture of 1:9 xylol-paraffin with incubation at $58^{\circ} \mathrm{C}$ for $24 \mathrm{~h}$. The materials were then infiltrated with paraffin at $58^{\circ} \mathrm{C}$. After $24 \mathrm{~h}$, replace with new paraffin. A 7 $\mathrm{mm}$ thick section was cut with Microtome (MICROM) and stained with $1 \%$ safranin solution and followed by placing in Xylol I, Xylol II, alcohol-xylol (1:3, 1:1, 3:1), alcohol series (100\% twice, 95\%, 80\%, 60\%, 40\%) 3 min. each. All of the stipe specimens were then photographed with a digital microscope (Celeron).

\section{RESULTS AND DISCUSSION}

In this study, we identified a total of four common fern species from 21 study sites in Pekanbaru, Riau Province (Table 2).

Table 2. List of examined species

\begin{tabular}{lll}
\hline Code Species & Family \\
\hline DL & Dicranopteris linearis (Burm.f.) Underw. & Gleicheniaceae \\
SP & Stenochlaena palustris (Burm.f.) Bedd. & Blechnaceae \\
NB & Nephrolepis biserrata (Sw.) Schott & Nephrolepidaceae \\
DD & Davalia denticulata (Burm.f.) Mett. ex Kuhn Davalliaceae \\
\hline
\end{tabular}

\section{Identification key}

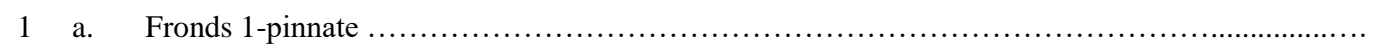

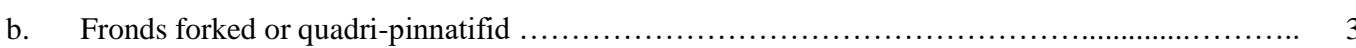

2 a. Rhizome suberect; young fronds densely hairy, light green; monomorphic; laminae lanceolate; sori round, one row at $1 / 3-1 / 2$ way from margin to costa with reniform indusia

Nephrolepis biserrata

b. Rhizome scrambling or climbing; young fronds smooth, brownish red; dimorphic; laminae of fertile frond lanceolate to oblong-lanceolate; laminae of sterile fronds linear; sori acrostichoid

3 a Rhizome, creeping, hairy; young frond green with loosely hair; monomorphic; primary rachisbranches usually twice forked, nearly equal, leafy branches up to $10 \mathrm{~m}$ or more; lamina light green when young, green at maturity; sori round, on the underside of leaves, arranged on both side of pinnae vein

\section{Stenochlaena palustris}

b. Rhizome scrambling, densely scaly throughout; young fronds reddish brown; dimorphic; rachis unbranched; laminae of sterile and fertile frond subtriangular, quadri-pinnatifid, pinnule lobed at the margin, lobus acute; laminae brownish dark red when young, light to dark green at maturity; sori small, located at very margin of lobes with cup-shaped indusia .... 


\section{Species enumeration}

Dicranopteris linearis (Burm.f.) Underw., Bull. Torrey Bot. Club 34: 249. 1907.

Synonym: Dicranopteris dichotoma (Thunb.) Bernh. $J$. Bot. (Schrader) 1801: 38 1806; Gleichenia dichotoma (Thunb.) Hook. Sp. Fil. 1: 12-13 12 1844; Gleichenia ferruginea Blume. Enum. Pl. Javae fasc. 2: 249 1828; Gleichenia hermanni R. Br. Prodr. 161 1810; Gleichenia lanigera D. Don. Prodr. Fl. Nepal. 17 1825; Gleichenia linearis (Burm. f.) C.B. Clarke. Trans. Linn. Soc. London, Bot. 1 (7): 428 1880; Glechenia rigida J., Sm. J. Bot. (Hooker) 3: 420 1841; Mertensia lessonii A. Rich.Sert. Astrol. 27 1834; Mertensia linearis (Burm. f.) Fritsch. Bull. Herb. Boissier, sér. 2, 1 (11): 1092 1901; Mertensia rufinervis Mart. Icon. Pl. Crypt. 1111834 Platyzoma ferrugineum Desv. Mém. Soc. Linn. Paris 6: 199 1827; Platyzoma latum Desv. Mém. Soc. Linn. Paris 6 : 199 1827; Polypodium lineare Burm. f. Fl. Indica 235, pl. 67, f. 2 1768; Polypodium pedatum Houtt. Nat. Hist. 2 (14): 174 1783; Pteris platylata Christenh. Phytotaxa 19: 222011 .

Description: Terrestrial. Rhizome long, brown, hairy, creeping and spreading along the ground or climbing on other vegetation and often forming deep thickets up to $3 \mathrm{~m}$ or more. Stems grow from the rhizome, greenish brown. Primary rachis-branches usually twice forked, nearly equal. Monomorphic. Leafy branches up to $10 \mathrm{~m}$ or more, especially when supported by the tree. The ultimate branches up to $30 \mathrm{~cm}$ or more, $5-8 \mathrm{~cm}$ wide. The ultimate segments of the leaves linear in shape, entire, apex rounded, up to $4 \mathrm{~mm}$ broad, firm, prominent vein. Sorus on the underside of leaves, round, light brown, arranged on both sides of pinnae vein.

Habitat: This species is found on the abandoned area, along the roadside, and other open spaced or partly shaded area.

Examined specimens: DL1A*, DL1B Tangkerang; DL1C, Simpang Tiga; DL2A, DL2B, DL2C Marpoyan Damai Collector Nery 2016: DL3A, DL3B, DL3C Tampan, Collector Nery \& Erlina 2016: DL4A Palas Collector Nery Dyah, Afni, Machfira, Ayu 2016; DL5A, DL5B, DL5C; Limbungan Collector Nery 2017; DL6A Sukajadi; DL7A, Tampan; DL8A, DL8B Kulim; DL9A Suka Maju; DL110A Kampung dalam Collector Nery 2016).

Local name: Paku Resam

Stenochlaena palustris (Burm.f.) Bedd., Suppl. Ferns Brit. Ind.: 26. 1876;

Synonym: Acrostichum palustre (Burm.f.) C.B. Clarke. Trans. Linn. Soc. London, Bot. 1 (9): 577 1880; Lomaria scandens (Sw.) Willd. Sp. Pl. 5 (1-2): 293-294 1810;

Lomariopsis palustris (Burm. F.) Kuhn. Ann. Mus. Bot. Lugduno-Batavi 4 (10): 294 1869; Lomariopsis scandens (Sw.) Mett. Fil. Lips. 22 1856; Olfersia scandens (Willd.) C. Presl. Tent. Pterid. 235 1836; Polypodium palustre Burm. F. Fl. Indica 234 1768; Pteris scandens (Willd.) Roxb. Calcutta J. Nat. Hist. 4: 505 1844; Stenochlaena scandens J.Sm. J. Bot. (Hooker) 3: 4011841.
Description: Terrestrial or hemi-epiphyte. Rhizome long, ca. $1 \mathrm{~cm}$ in diameter, creeping, scrambling or climbing on other vegetation, stout, light brown. Dimorphic, sterile and fertile pinnae on the different frond. Sterile frond ca. up to $80 \mathrm{~cm}$ long or more, stipes $25 \mathrm{~cm}$ or more, glabrous; rachis glabrous, up to $55 \mathrm{~cm}$ or more; laminae brownish red when young, dark green at maturity, 1-pinnate, with up to 25 pinnae; pinnae opposite, lanceolate to oblonglanceolate, cuneate at the base with serrate margin, glabrous, upperside glossy, c. $15 \mathrm{~cm}$ long, $3 \mathrm{~cm}$ wide or more, rounded at the base, shortly stalked (ca $3 \mathrm{~mm}$ ), blackish green, tip acute, veins anastomosing. Fertile frond ca. $90 \mathrm{~cm}$ long, stipes up to $17 \mathrm{~cm}$; rachis up to $40 \mathrm{~cm}$; fertile pinnae 25 , yellowish brown when young, dark brown at maturity, up to $22 \mathrm{~cm}$ long, $4 \mathrm{~mm}$ wide, linear and covered by sporangia on the whole lower surface, margin curved upward forming a narrow row.

Habitat: this species can be found on the ground, scrambling on the other vegetation or fence. It often found on the open space, partly shaded area and some time on the shaded area.

Examined specimens: SP1A, SP1B, SP1C Simpang Tiga; SP2B*, SP2C Maha Ratu; SP3A, SP3B, SP3C Tampan Collector Nery 2016; SP4A, SP4B, SP4C Collector Nery, Dyah, Afni, Machfira, Ayu 2016; SP5A Limbungan Collector Nery 2017; SP7A, SP7B, SP7C Tampan; SP8A, SP8B Kulim; SP9A Cinta Raja; SP110A Kampung Dalam Collector Nery 2016.

Note: The young frond is edible and commonly consumed by local people as a vegetable.

Nephrolepis biserrata (Sw.) Schott Gen. Fil. pl. 3: 1834.

Synonym: Aspidium acuminatum Willd. Sp. Pl. 5: 221 1810; Aspidium acutum Schkuhr. Deutschl. Krypt. Gew. 1: 32, pl. 31 1809; Aspidium bisseratum Sw. J. Bot. (Schrader) 1800 (2): 32 1801; Aspidium ensifolium Schkuhr. Deutschl. Krypt. Gew. 1: 32, t. 32 1806; Aspidiumguineense Schumach. Kongel. Danske Vidensk. Selsk. Naturvidensk. Math. Afh. 4: 229 1829; Aspidium punculatum Sw. Syn. Fil. 46 1806; Hypopeltis biserrata (Sw.) Bory. Voy. Indes Or. 2: 65 1833; Lepidoneuron bisseratum (Sw.) Fee. Mém. Foug. 5: 301 1852; Lepidoneuron punctulatum (Poir.) Fee. Mem. Foug., Gen. Filic. 301 1852; Lepidoneuron rufescens (Schrad.) Fee. Mém. Foug. 5: 301 1852; Nephrodium acuminatum (Willd.) C.Presl.Reliq. Haenk. 1 (1): 31 1825; Nephrodium acutum (Schkuhr) C. Presl. Reliq. Haenk. 1 (1): 31 1825; Nephrodium bisseratum (Sw.) C.Presl. Reliq. Haenk. 1 (1): 31 1825; Nephrodium punctulatum (Sw.) Desv.Mém. Soc. Linn. Paris 6: 253 1827; Nephrodium rufescens Schrad. Gott. Gel. Anz. 869 1824; Nephrolepis acuminata (Willd.) C.Presl.Tent. Pterid. 79 1836; Nephrolepis acuta (Schkuhr) C. Presl. Tent. Pterid. 79 1836; Nephrolepis bisserata subsp. punctulata (Poir.) Bonap. Notes Pteridol. 1: 165165 1915; Nephrolepis ensifolia (Schkuhr) C. Presl. Tent. Pterid. 79 1836; Nephrolepis exalta var. biserrata (Sw.) Bake. Fl. Bras. 1 (2): 493 1870; Nephrolepis hirsutula var. acuta (Schkuhr) Kuntze. Revis. Gen. Pl. 2: 816 1891; Nephrolepis hirsutula var. biserrata (Sw.) Kuntze. Revis. Gen. Pl. 2: 816 1891; Nephrolepis mollis Rosenst. Repert. 
Spec. Nov. Regni Veg. 22 (606-608): 13 1925; Nephrolepis punctulata (Poir.) C. Presl. Tent. Pterid. 79 1836; Nephrolepis rufescens (Schrad.) C. Presl ex Wawr. Bot. Ergebn. 200, t. 101 1866; Polypodium nephrolepioides $\mathrm{H}$. Chist. Bull. Soc. Bot. Genève 1 (5): 220, text f. 1909; Polypodium punctulatum Poir. Encycl. 5: 533-534 1804; Tectaria Fraxinea Cav. Descr. Pl. 2501802.

Description: Hemiepiphyte. Rhizome suberect, bearing a few fronds, root wiry, up to $5 \mathrm{~mm}$ in diameter, scaly. Scale narrowing toward apex. Young frond densely hairy, usually white. Stipes up to $50(-110) \mathrm{cm}$ long, stramineous, densely scaly. Laminae lanceolate, both apex and base narrowing, 1-pinnate. Pinnae articulate, up to $13 \mathrm{~cm}$ long or more, ca $2 \mathrm{~cm}$ broad, linear to lanceolate, apex acuminate, base cuneate, margin serrate, thin, shortly stalk. Stalk ca 2 $\mathrm{mm}$. Veins forked. Sori round, one row at $1 / 3-1 / 2$ way from margin to costa with reniform indusia.

Habitat: This species can be found on the ground at the open space area or on the other vegetation as epiphytic fern. We record that the main host of this species is oil palm tree. However, it can grow on the rotten bark, humid broken wall and among the other flora on open space area.

Examined specimens: B1A, NB1B, NB1C Simpang Tiga, NB2A, NB2B Marpoyan Damai, NB2C Maha Ratu Collector Nery 2016; NB3A, NB3B, NB3C, Tampan, Collector Nery \& Erlina 2016; NB4A, NB4B, NB4C Rumbai Collector Nery, Dyah, Afni, Machfira, Ayu 2016; NB5A, NB5B, NB5C; Limbungan Collector Nery 2017; NB6A Sukajadi; NB7A, NB7B, NB7C Tampan; NB8A, NB8B, NB8C Kulim; NB9A Cinta Raja; NB110A, Kampung Dalam Collector Nery 2016

Note: The vernacular name of this species is "Paku Pedang" (sword fern), and some time used as ornamental plant in this urban area.

Davalia denticulata (Burm.f.) Mett. ex Kuhn Filic. Afr. 27: 1868.

Synonym: Adiantum denticulatum Burm.f. Fl. Indica 236 1768; Davallia chaerophylloides (Poir.) Steud. Nomencl. Bot. 2: 146 1824; Davallia denticulata var. intermedia Mett. ex Kuhn. Filic. Afr. 158 1868; Davallia elegans Sw. J. Bot. (Schrader) 1801: 87 1801; Davallia schnellii Tardieu. Notul. Syst. (Paris) 13: 372 1948; Davallia vogelii Hook. Sp. Fil. 1: 168, t. $59 B$ 1846; Humata chaerophylloides (Poir.) Desv. Mém. Soc. Linn. Paris 6 (2): 325 1827; Humata elegans (Sw.) Desv. Mém. Soc. Linn. Paris 6: 324 1827; Parestia elegans (Sw.) C. Presl. Abh. Königl. Böhm. Ges. Wiss., ser. 5 6: 459 1851; Trichomanes chaerophylloides Poir. Encycl. 8: 80 1808; Trichomanes denticulatum (Burm. f.) Houtt. Nat. Hist. 2 (14): 2121783.

Description: Epiphyte. Rhizome long creeping, ca. $1 \mathrm{~cm}$ in diameter, yellowish brown, densely scaly throughout. Scale light brown, ovate at the base, patent tail. Dimorphic.
Sterile frond. Stipes brown, terete, glabrous, up to $45(-55)$ $\mathrm{cm}$ long. Laminae dark green, subtriangular, narrowing towards apex, quadri-pinnatifid, up to $65(-65) \times 45(-55)$ $\mathrm{cm}$. Pinnae 51, cuneate at the base, stalked, $25(-30) \mathrm{cm}$ long, Pinnule lobed at the margin, lobus acute, ca $0,5 \mathrm{~mm}$ broad. Fertile frond. Stipes brown, terete, glabrous, up to 35 (-45) cm long. Laminae brownish dark red when young, light to dark green at maturity, subtriangular, narrowing towards apex, quadri-pinnatifid, up to $45(-50) \times 40(-45)$ $\mathrm{cm}$. Pinnae 43, cuneate at the base, stalked, $20(-25) \mathrm{cm}$ long, Pinnule lobed at the margin, lobus acute, ca $0,5 \mathrm{~mm}$ broad. Sori small, located at the very margin of lobes with cup-shaped indusia.

Habitat: This species is commonly found as epiphytic fern on the other vegetation, especially on oil palm tree (Elaeis guineensis Jacq.). We also identified other plant hosts, i.e., Rambutan (Nephelium lappaceum L.), Akasia (Acacia sp.)

Examined specimens: DD1C Tangkerang Selatan, Collector Nery 2016; DD2B, DD2C Tangkerang Barat, Collector Nery 2016; DD3A, DD3B, DD3C Tampan, Collector Nery \& Erlina 2016; DD4A, DD4BN DD4C Rumbai Collector Nery, Dyah, Afni, Machfira, Ayu 2016; DD5A, DD5B, DD5C Limbungan Collector Nery 2017; DD6A, DD6B Suakajadi DD6C Kampung Tengah Collector Nery 2016; DD7B Tampan Collector Erlina 2017 DD7C Delima Collector Nery 2016; DD8A, DD8B Kulim ; DD8C Tangkerang Timur, Collector Nery 2016; DD9A, DD9B, DD9C Cinta Raja Collector Nery 2016; DD110A, Kampung Dalam Collector Nery 2016.

\section{Palynology}

Spore is a reproduction unit on algae, fungi, bryophyte, and pteridophyte (fern). In fern, spore morphology becomes the characteristic among the members and support the taxonomical task (Sofiyanti et al. 2015a). Figure 3 presents the spore morphology of four examined species, while Table 3 shows the spore features. We observed two types of spore in this study, monolete and trilete. Monolete spore (Figure 3.A-C) is a spore with single elongate scar called laesura. It is also characterized by having kidneyshaped grain, while trilete spore (Figure 3.D) has trichotomous laesura with tricomonosulcate aperture. These two spore types were also reported for the Pteridaceae from Chevron Forest, Rumbai, Riau (Marpaung et al. 2016) as well as other fern species (Moran et al. 2007; Sofiyanti et al. 2017; Xiao-Ying et al. 2010; Zenkteler 2012). Three out of four ferns examined in this study have monolete spore, i.e. Stenochlaena palustris (Figure 3a), Nephrolepis biserrata (Figure 3.B), and Davalia denticulata (Figure 3.C). The only fern species with trilete spore in this study is Dicranopteris linearis (Figure 3.D). This result in accordance with the fern spore study by Makgomol (2006). 


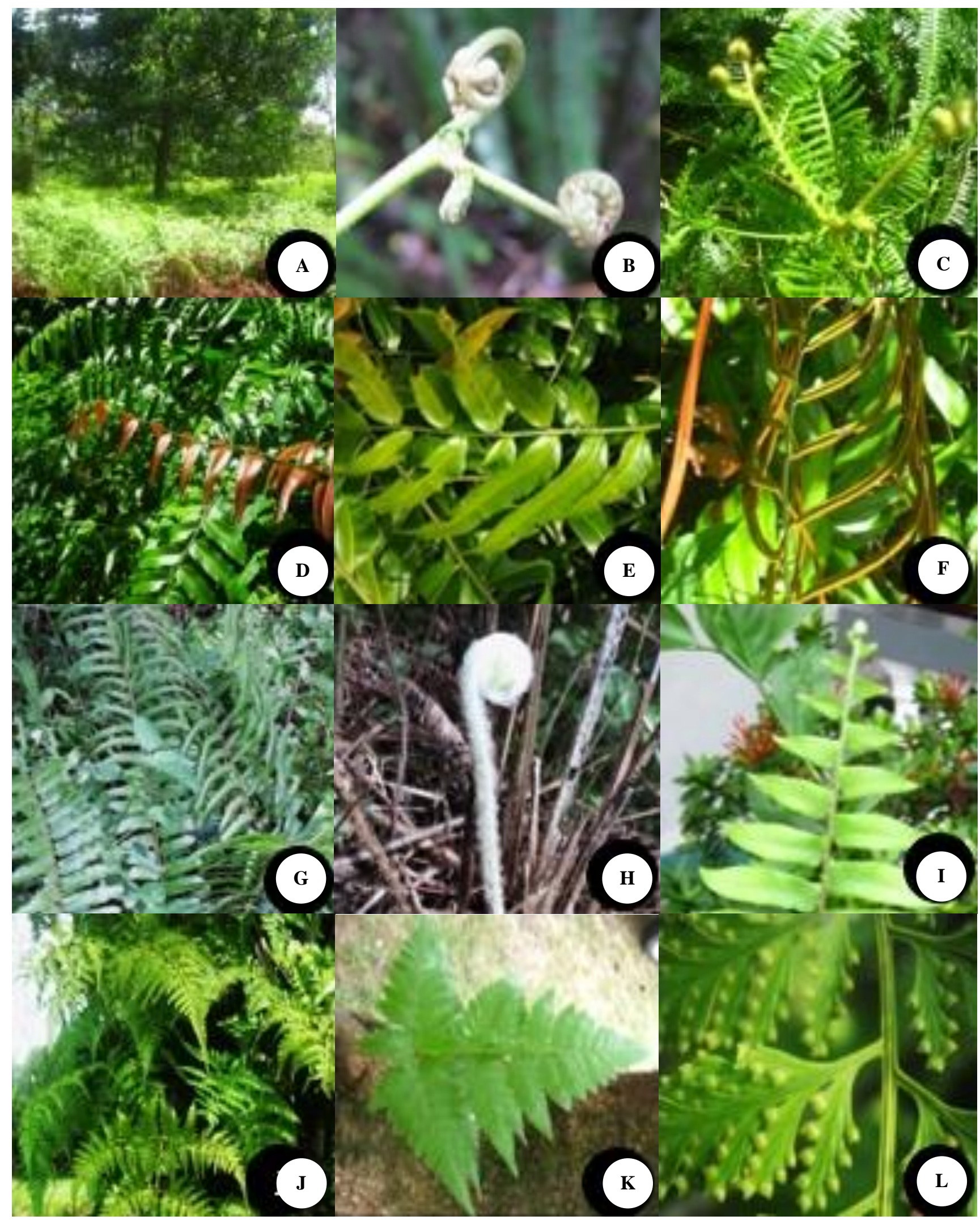

Figure 2. Morphology of four common ferns from Pekanbaru, Riau. A-C. Dicranopteris linearis (a. Habitus, b. forked young frond, c. laminae), D-F. Stenochlaena palustris (d. Habitus, e. sterile frond, e. fertile frond), G-I. Nephrolepis biserrata (g. Habitus, h. hairy young frond, i. laminae), J-L. Davallia denticulata (j. habitus, k. sterile frond, l. fertile frond showing sori). 

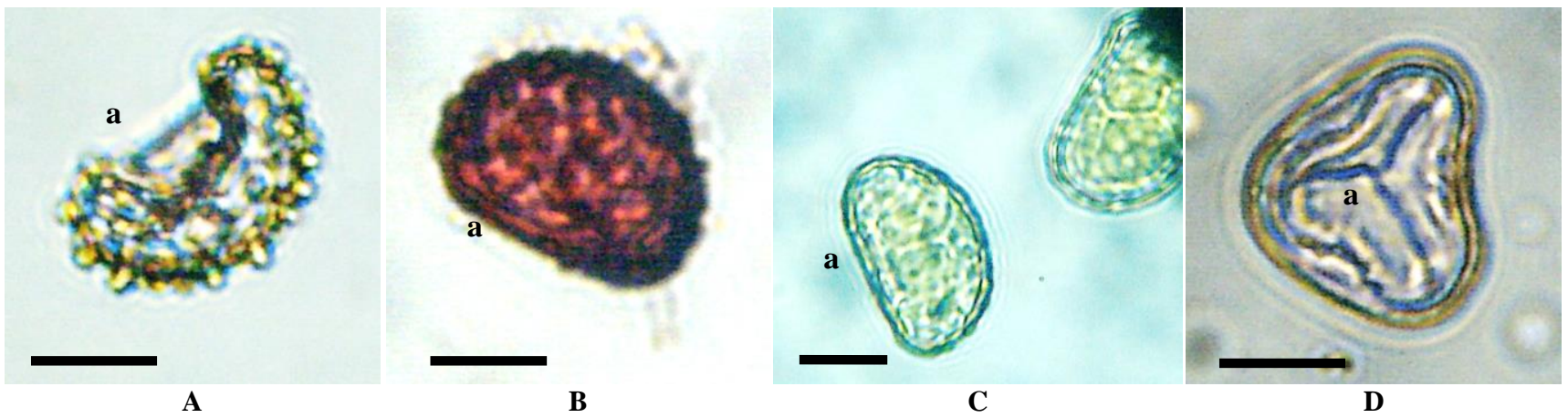

Figure 3. Spore morphology. A. Stenochlaena palustris, B. Nephrolepis bisserata, C. Davalia denticulata, D. Dicranopteris linearis. Note: $\mathrm{a}=$ laesura. Scale $\mathrm{bar}=20 \mu \mathrm{m}$

Table 3. The spore features

\begin{tabular}{lllllll}
\hline $\begin{array}{c}\text { Species } \\
\text { code }\end{array}$ & \multicolumn{1}{c}{ Type and aperture } & Size & Size type & P/E & Shape & Ornamentation \\
\hline SP & Monolete, disulcate & $58.73 \pm 4.68$ & Big & 1.47 & Prolate & Massues \\
NB & Monolete, monosulcate & $48.49 \pm 4.99$ & Medium & 1.47 & Prolate & Verrucate \\
DD & Monolete, monosulcate & $39.23 \pm 5.75$ & medium & 1.26 & Subprolate & Verrucate \\
DL & Trilete, tricho monosulcate & $50.44 \pm 5.23$ & Big & 1.22 & Subprolate & Psilate \\
\hline
\end{tabular}

The monolete spore of $S$. palustris examined in this study support the basic spore type of Blechnaceae including Blechnum (Nayar and Devi 1964; Passarelli et al. 2010) and Stenochlaena (Sofiyanti et al. 2016). Stenochlaena palustris has disulcate aperture, i.e. two apertures with sulcus shape. In contrast Nephrolepis biserrata and Davalia denticulata have monosulcate aperture (one aperture with sulcus shape). The only fern species with trilete spore in this study is Dicraopteris linearis (Figure 3.d). This spore type was also found in other genera such as Adiantum, Pteris, Lygodium, and Lindsaea (Makgomol 2006).

There is two spore size found in this study, i.e., medium (Nephrolepis biserrata and Davalia denticulata.) and big spore (Dicranopteris linearis and Stenochlaena palustris). According to Erdtman (1945) in Edrtmand (1957), the size of medium and big spore range from 20-50 $\mu \mathrm{m}$ and 50-100 $\mu \mathrm{m}$, respectively. The biggest spore belongs to Stenochlaena palustris, with the longest axis is $58,73 \pm$ $4,68 \mu \mathrm{m}$. Based on the observation of Polar-equatorial (P/E) ratio, we identified two spore shapes, i.e., subprolate and prolate. The range of $\mathrm{P} / \mathrm{E}$ Ratio subprolate spore is 1,44-1,33, while prolate is 1,33-2,00 (Erdtman 1957).

The other spore characteristic is ornamentation. We observed three ornamentations, i.e., massues, verrucate, and psilate. According to Agashe and Caulton (2009), the massues spore has small knobby ornament on the outer spore surface. This ornamentation was found in
Stenochlaena palustris (Figure 3.a.). The verrucate ornamentation is wart-like ornamentation. Two species that have verrucate ornamentation are Nephrolepis bisserata and Davalia denticulata, while Dicranopteris linearis has psilate ornamentation, with the smooth surface.

\section{Stipe anatomy}

The study of stipe anatomy had been reported on some fern species. Some Malaysian ferns had been examined their stipe anatomy, such as Gleicheniaceae including Dicranopteris linearis (Yen 2006), Davallia, including Davallia denticulata (Talib et al. 2012), Blechnum (Talip et al. 2014). While Resmi et al. (2016) reported the stipe anatomy of Adiantum, Drynaria, Lygodium, Marsilea, Pityrogramma, and Pteris from South India. In this study, we examined the stipe anatomy of all fern species in this study. Figure 4 shows the cross section of stipes, while the characteristic of stipe anatomy presented in Table 4. Figure $4(\mathrm{~A}, \mathrm{E}, \mathrm{H}$, and $\mathrm{K})$ present the variation of cross section stipes, i.e., almost ovale (Figure 4.A), c-shaped (Figure 4.E and $\mathrm{H}$ ) and rounded (Figure 4.K). The epidermis is the outer layer of plant anatomy that covering plant body and usually consisted of a single layer of the cell. All of four species in this study have single layer epidermis, consisting of polygonal cells. Cortex is a cell layer beneath epidermis towards inner side, that consisted of polygonal cells with multilayer arrangement. 


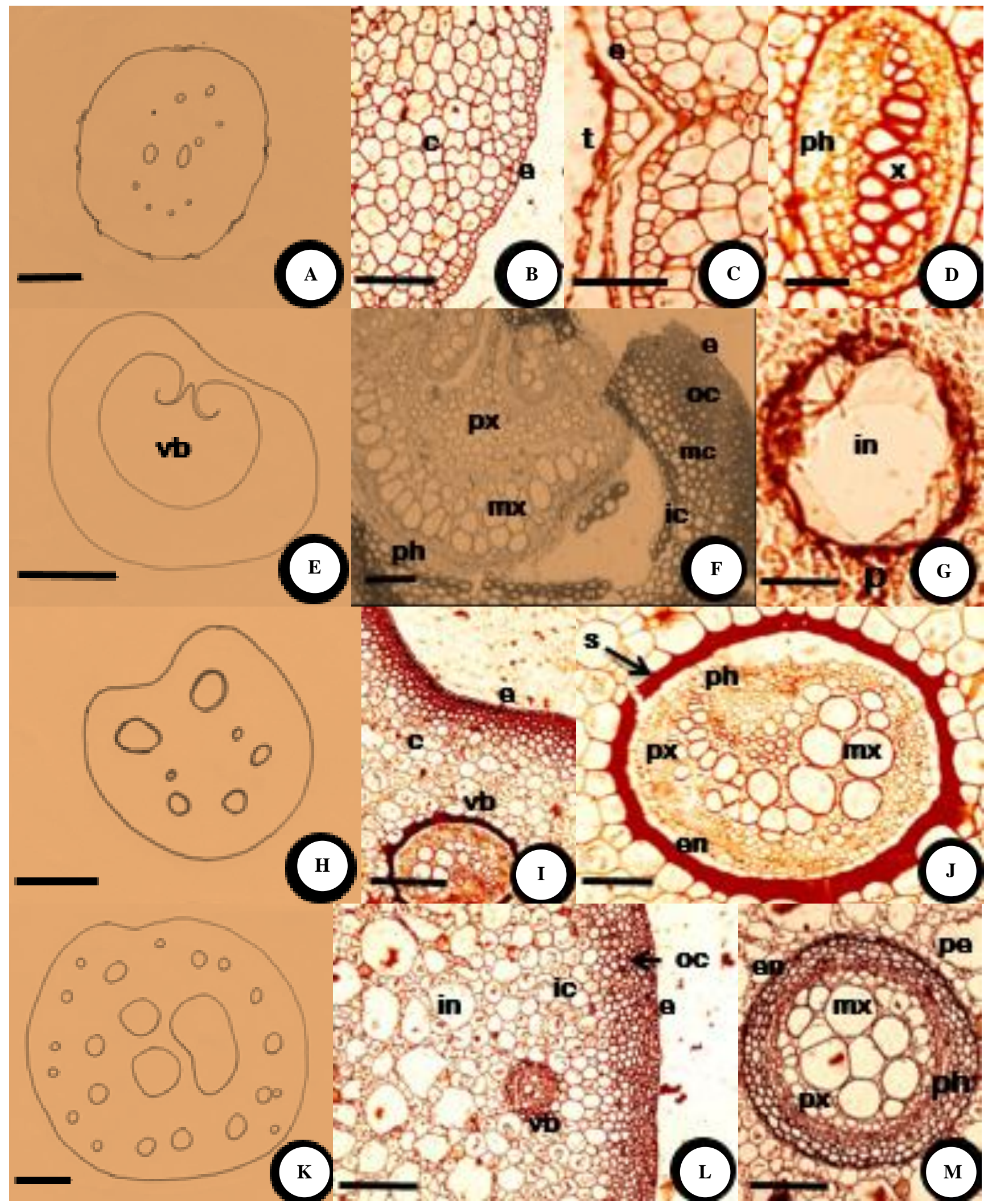

Figure 4. Cross section of stipe. A-D. Davalia denticulata (a. vascular bundle pattern, b. epidermis and cortex, c. trichome, d. vascular bundle), E-G. Dicranopteris linearis (e. hand drawing of vascular bundle pattern, f. part of cross section. g. intercelullar cell), H-J. Nephrolepis biserrata (h. vascular bundle pattern, i. epidermis, and cortex, j. vascular bundle surrounded by schlerenchymatous layer), K-M. Stenochlaena palustris (k. vascular bundle pattern, l. epidermis, outer and inner cortex, $\mathrm{m}$. vascular bundle with pericycle beneath endodermis). Note: Left figures are handwritings. $\mathrm{e}=$ epidermis, $\mathrm{c}=$ cortex, oc $=$ outer cortex, ic $=$ inner cortex, en $=$ endodermis, in $=$ intercellular cell, $\mathrm{pe}=$ pericycle, $\mathrm{v}=$ vascular bundle; $\mathrm{ph}=$ phloem $, \mathrm{x}=\mathrm{xylem}, \mathrm{mx}=$ metaxylem, $\mathrm{px}=$ protoxylem, $\mathrm{s}=\mathrm{sclerenchyma}, \mathrm{t}=$ trichome. Scale bar: $2 \mu \mathrm{m}$ (C, D, G, K); $5 \mu \mathrm{m}$ (B, F, J); $10 \mu \mathrm{m}$ (I, L); $20 \mu \mathrm{m}$ (A, E, H, K). 
Table 4. Stipe anatomy

\begin{tabular}{|c|c|c|c|c|c|c|c|}
\hline Code & EL & $\mathrm{CZ}$ & COR & VB & NVB & VBS & Stele \\
\hline $\mathrm{DL}$ & 1 & 1 & $\begin{array}{l}\text { Multilayers, thin walls with small } \\
\text { intercellular cells }\end{array}$ & $\mathrm{AC}$ & 1 & $\begin{array}{l}\text { Heart-shaped, curved at both } \\
\text { upper side towards inner side }\end{array}$ & Atactostele \\
\hline DD & 1 & 3 & $\begin{array}{l}\text { OC multilayers; thick wall. } \\
\text { MC multilayers; thin wall } \\
\text { IN } 2 \text { layers, thick wall. }\end{array}$ & $\mathrm{AC}$ & 11 & Rounded, oval & Atactostele \\
\hline NB & 1 & 2 & $\begin{array}{l}\text { OC Multilayers; thik wall IN thin } \\
\text { wall }\end{array}$ & $\mathrm{AC}$ & 7 & Rounded & Atactostele \\
\hline SP & 1 & 1 & $\begin{array}{l}\text { Multilayer, thin wall; big } \\
\text { intersellular cells }\end{array}$ & $\mathrm{AC}$ & 23 & Rounded, reniform & Atactostele \\
\hline
\end{tabular}

Note: $\mathrm{EL}=$ epidermis layer, $\mathrm{CZ}=$ cortex zone, $\mathrm{COR}=$ cortex, $\mathrm{OC}=$ outer cortex, $\mathrm{MC}=$ middle cortex, $\mathrm{IN}=$ innermost cortex, $\mathrm{VB}=$ vascular bundle, $\mathrm{NVB}=$ number of vascular bundle, $\mathrm{VBS}=\mathrm{V}$ ascular bundle shape, $\mathrm{AC}=$ amphicribal concentric.

The zone of cortex may vary on the species. One zone cortex was found in Davallia denticulata. Two zone cortex was found in two species, i.e. Nephrolepis biserrata and Stenochlaena palustris. In the first species, the outer zone consists of thick wall sclerenchymatous cells, arranged in 4 - 5 layers. While the inner zone comprises of a larger thin wall polygonal cell. This cortex arrangement is similar to Cheilantes tenuifolia reported by Meerabai (2012). While Stenochlaena palustris has numerous big intercellular cells (Figure 4k), especially towards inner side.

Cortex with three zones was found in Dicranopteris linearis (Figure 4f). The cortex is divided into three different layers, i.e., outer, middle and innermost cortex. Outer and middle cortex consisted of multilayer cells. However, the outer cortex cells have a thick wall, while the middle one is thin. The innermost cortex consisted of two cell layers with a thick wall $( \pm 2 \mu \mathrm{m})$. This species is also characterized by having numerous big intercellular cells (Figure 4g). Our observation of vascular bundles found that they varied in size and shape in four examined species (Figure 4, Table 4). Davallia denticulata has 11 vascular bundles with rounded and oval shapes. The size of the vascular bundle of this species is smaller than other species in this study. The rounded vascular bundle is also found in Nephrolepis biserrata and Stenochlaena palustris. The unique shape of vascular bundle is found in Dicranopteris linearis. This species has one vascular bundle only with heart-shaped that curved at both upperside towards inner side, that becomes the characteristic of this species and gives an important anatomical data for the systematics of Dicranopteris linearis.

The type of vascular bundles or four species observed is similar, i.e concentric bundle, because in cross section the xylem and phloem form a concentric ring. In this type of bundle, phloem surrounds xylem, therefore, called amphicribral or also well known as hadrocentric. This type is very common in the fern. Each vascular bundle in this study is surrounded by one layer endodermis. The clear schlerenchymatous layer that surrounds endodermis is only found in Nephrolepis biserrata (Figure 4i). For Stenochlaena palustris, multilayer pericycle cells are found beneath endodermis (Figure 4h). Pericycle consists of parenchyma or sclerenchyma cells, that considered part of the vascular cylinder that formed from procambium as other vascular tissue. Most of the vascular bundle shape in Stenochlaena palustris are rounded, and only one big reniform-shaped that consisted of two vascular bundles (Figure $4 \mathrm{j}$ ). The number of vascular bundles varies within the species, range from 1 to 23. However, even though Dicranopteris linearis has only one vascular bundle the size is very large. The stele type of all species in this study is atactostele, in which vascular bundle sparsely distributed. This stele also found in other fern members such as Lygodium and Selaginella (Khullar 2008). The vascular bundle consists of xylem and phloem. Xylem has simple tracheids that vary in size, known as metaxylem and protoxylem. Metaxylems have scalariform and pitted thickenings, while protoxylems have had annular and spiral thickening.

In conclusion, a total of four common ferns from Pekanbaru were identified in this study, with two species are monomorphic (Nephrolepis biserrata and Dicranopteris linearis), the others are dimorphic (Stenochlaena palustris and Davalia denticulata). The cross-section of stipes of each species showed a layer of the epidermis, while the cortex layer varied from 1 (Davallia denticulata), 2 (Nephrolepis biserrata and Stenochlaena palustris) and 3 (Dicranopteris linearis). All of four species had a similar vascular bundle, amphicribral concentric, with atactostele. The monolete spore was found in three species (Nephrolepis biserrata, Davalia denticulata, and Stenochlaena palustris), while trilete spore was found in Dicranopteris linearis. The results of this study give important data for lower plant taxonomists in description, identification, characterization and classification tasks.

\section{ACKNOWLEDGEMENTS}

This study was supported by PTUPT (Penelitian Terapan Unggulan Perguruan Tinggi) grant 2017, Ministry of Research, Technology and Higher Education of the Republic of Indonesia, led by the first author. 


\section{REFERENCES}

Agashe SN, Caulton E. 2009. Pollen and Spores: Applications with Special Emphasis on Aerobiology and Allergy. CRC Press, Boca Raton, FL.

Aldasoro JJ, Cabezas F, Aedo C. 2004. Diversity and distribution of ferns in Sub-Saharan Africa, Madagascar and some islands of The South Atlantic. J Biogeogr 31: 1579-1604.

Erdtman G. 1957. Pollen and Spore Morphology and Plant Taxonomy: Gymnospermae, Pteridophyta, Bryophyta, (Illustrations). Almqvist and Wiksell. Stockholm.

Guillon J. 2004. Phylogeny of horsetails (Equisetum) based on the chloroplast rps 4 gene and adjacent noncoding sequences. Syst Bot 29 (2): 251-259.

Huiet L, Lenz M, Nelson JK, Pryer KM, Smith R. 2015. Adiantum shastense, a new species of maidenhair fern from California PhytoKeys 53: 73-81.

Johansen AD. 1940. Plant Microtechnique. McGraw-Hill Book Company, Inc. London.

Khullar SP. 2008. Diversity of Microbes and Cryptogams-Pteridophyta Department of Botany, Panjab University Chandigarh.

Lindsay S, Middleton DJ, Suddee S. 2008. Two new species of ferns from Thailand. Thai For Bull (Botany) 36: 46-51.

Makgomol, K. 2006. Morphology of fern spores from Phu Phan National Park. Kasetsart J (Nat Sci) 40: 116 - 122.

Marpaung AA, Sofiyanti N, Iriani D, Fitmawati. 2016. Morfologi spora paku Pteridaceae di Hutan PT. CPI Rumbai Riau. Jurnal Riau Biologia 1 (2): 148-154. [Indonesian]

Meerabai G. 2012. Stem and petiole anatomy Of Chelienthes Tenuifolia (Burm) Sw Syn Fill (Pteridaceae, Pteridophyta). Indian J Plant Sci 1 (1): .22-24.

Moran RC, Hanks JG, Rouhan G. 2007. Spore morphology in relation to phylogeny in the fern genus Elaphoglossum (Dryopteridaceae). Intl J Plant Sci 168 (6): 905-929.

Nagalingum, N, Schneider H, Kathleen P. 2006. Comparative morphology of reproductive structures in heterosporous water ferns and a reevaluation of the sporocarp. Intl J Plant Sci 167 (4): 805-815.

Nayar BK, Devi S. 1964. Spore morphology of Indian Ferns II. Aspleniaceae and Blechnaceae. Grana Palynologica 5 (2): 222-246. DOI: $10.1080 / 00173136409430016$

Passarelli L, Galán JMG, Prada C, Rolleri CH. 2010. Spore morphology and ornamentation in the genus Blechnum (Blechnaceae). Grana 49 (4): 243-262

Piggott AG. 1998. Fern of Malaysia in Color. Tropical Press Sdn.Bhd., Malaysia.
Resmi S, Thomas VP, Sreenivas VK. 2016. Stipe anatomical studies on selected Pteridophytes of South India. Acta Botanica Hungarica 58 (1-2): 167-176

Rojas-Alvarado F. 2017. Three new species of ferns (Pteridophyta) from Mesoamerica Alexander. Amer J Plant Sci 8: 1329-1338.

Sofiyanti N. 2013. The diversity of epiphytic fern on the oil palm tree (Elaeis Guineensis Jacq.) in Pekanbaru, Riau. Jurnal Biologi XVII (2): 51-55.

Sofiyanti N, Iriani D, Roza AA. 2015. Morfologi tumbuhan Paku di Taman Hutan Raya Sultan Syarif Hasyim, Riau. Unri Press, Pekanbaru. [Indonesian]

Sofiyanti N, Iriani D, Fitmawati, Roza AA. 2015. Stenochlaena riauensis (Blechnaceae), A new fern species from Riau, Indonesia. Bangladesh J Plant Taxon 22 (2): 137-141.

Sofiyanti N, Mat-Salleh K, Mahmud K, Mazlan NZ, Hasein MRA, Burslem DFRP. 2016. Rafflesia parvimaculata (Rafflesiaceae), a new species of Rafflesia from Peninsular Malaysia. Phytotaxa 253 (3): 207-213.

Sofiyanti N, Iriani D, Fitmawati, Marpaung AA. 2017. Karakteristik dan Metode Pembuatan Preparat Spora Pteridoflora. UNRI Press, Pekanbaru. . [Indonesian]

Talip N, Ruzi A, Nadiah N, Nisa RN, Kader H, Solihani SN. 2012. Stipe anatomical characteristics in some Davallia (Davalliaceae) species in Malaysia. Sains Malaysiana 41: 53-62.

Talip N, Aiman M, Jaman R, Nor-Fairuz AR, Kader H, Damanhuri A, Ruzi A. 2014. Systematic significance of stipe anatomy in peninsular Malaysian Blechnum L. (Blechnaceae) species. Malaysian Appl Biol 43: 119-128.

Wulandari D, Sofiyanti N, Fitmawati. 2016. Keanekaragaman jenis Polypodiaceae di Hutan PT. CPI Rumbai Provinsi Riau berdasarkan karakter morfologi. Jurnal Riau Biologia 1 (2): 135-139. [Indonesian]

Yusna M, Sofiyanti, Fitmawati. 2016. keanekaragaman Pteridaceae berdasarkan karakter morfologi dan fitokimia di Hutan PT. Chevron Pacific Indonesia (PT. CPI) Rumbai. Jurnal Riau Biologia 1 (2): 165172. [Indonesian]

Vahdati FB, Mehrvarz SS, Naqinezhad A, Shavvon RS. 2014. The morphological and anatomical reinvestigation of the Psilotum nudum, in Hyrcanian forests, N Iran. Taxon Biosyst 21: 87-96.

Xiao-Ying H, Jun-Wen Z, Fa-Guo W, Xin-Lan X. 2010. Simple treatment to investigate spore ornamentation of ferns for sem observation from herbarium specimens. Pakistan J Bot 42 (4): 2335-2338.

Yen CL. 2006. Morphological and Anatomical Variations among the Genera of Gleicheniaceae. [Thesis]. Universiti Putra Malaysia, Kuala Lumpur.

Zenkteler E. 2012. Morphology and peculiar features of spores of fern species occurring in Poland. Acta Agrobotanica 65 (2): 3-10. 